\title{
SURVEY OF THE LAW OF ProfeSSIONAL RESPONSIBILITY (2019)
}

\author{
CHARLES M. KIDD*
}

\section{IN RE WELKE, 131 N.E.3D 161 (IND. 2019)}

The client in this matter was charged with murder in 2010 and was represented by a public defender. ${ }^{1}$ The client's English language skills were poor and his counsel had to use the services of an interpreter. The public defender and the prosecuting attorney engaged in plea negotiations that resulted in an agreement whereby the defendant would enter a guilty plea to involuntary manslaughter and receive a fixed or maximum term of imprisonment of thirty years. $^{2}$ The public defender had two good reasons to support the client's acceptance of this plea: He believed the self-defense argument would fail, and he had a compelling case to offer in mitigation. ${ }^{3}$

Meanwhile, the respondent's legal assistant, Joseph Everroad, ingratiated himself with the client's family. ${ }^{4}$ Everroad - with respondent's help - convinced the client that his public defender was selling out the client with the plea offer. They also convinced the client that the respondent could make the self-defense claim successful at trial. In the alternative, they claimed, they could get a better plea deal for the client. ${ }^{5}$ As a result, the family hired the respondent for $\$ 6,000$ along with an additional $\$ 1,000$ to pay for an interpreter. ${ }^{6}$

The respondent had never handled a murder case and had little experience with major felony defense overall. ${ }^{7}$ The respondent did not hire an interpreter, and neither he nor Everroad had adequate language fluency to be able to communicate effectively with the client. The respondent did not meet with the client and left that task to Everroad. On one occasion, Everroad brought a woman to the jail who needed community service credit, and she served as an interpreter. ${ }^{8}$ Everroad attempted to reassure the client he had a strong self-defense case, but he never returned with an interpreter. He said later the purpose of these meetings was to keep the client happy so the respondent could get "get the rest of his money out of the client."'

Shortly before the trial date, the respondent looked at the post-mortem

* Deputy Executive Director, Indiana Supreme Court Disciplinary Commission. J.D. McKinney School of Law (1988), B.S. Butler University (1979). The author thanks law clerks (and McKinney students) Jordan Quillen and Calvin Blank for their assistance in the research for this survey.

1. In re Welke, 131 N.E.3d 161 (Ind. 2019).

2. Id. at 162 .

3. $I d$.

4. $I d$.

5. $I d$.

6. $I d$.

7. Id. at 163.

8. $I d$.

9. Id. 
photographs of the victim for the first time and concluded that the self-defense claim would be untenable at trial. ${ }^{10}$ At the final pretrial conference, the State offered a plea agreement providing that in exchange for a guilty plea to a charge of voluntary manslaughter, the State would agree to a sentence of forty years. The respondent attempted to accept that agreement on behalf of his client, but the client balked, and the trial went forward three days later. ${ }^{11}$

The respondent was unprepared for the trial and did not employ an interpreter to assist in communicating with his client during the trial, either. ${ }^{12}$ During a recess (and using a friend of the client as an interpreter), the respondent communicated the State's latest offer to the client and urged him to take the deal because his defense was weak. ${ }^{13}$ The client then accepted the offer, pleaded guilty to murder, and accepted a sentence of forty-five years. The client's guilty plea was subsequently vacated during post-conviction proceedings due to the ineffective assistance of counsel. ${ }^{14}$ The respondent's performance was so deficient that the client could not enter a knowing and voluntary plea. The murder case was retried in 2016, when a jury found the client guilty of murder, and he was subsequently sentenced to fifty-five years in prison. ${ }^{15}$

During the Disciplinary Commission's investigation, the respondent falsely told the Commission that the client was a fluent English speaker. ${ }^{16}$ The Court found this was a violation of rule 8.1(a) of the Rules of Professional Conduct. ${ }^{17}$ In addition, the respondent's misconduct was also found to violate Rules $1.1,{ }^{18}$ $1.3,{ }^{19} 1.4(\mathrm{a})(2),{ }^{20}$ and 5.3(b). ${ }^{21}$ In a shorthand fashion, the respondent's violations

10. Id.

11. Id.

12. Id.

13. Id.

14. Id. at 163 n. 3 .

15. Id. at 163 n. 2 .

16. Id. at 163 .

17. Id. Rule 8.1(a) provides, "[a]n applicant for admission to the bar, or a lawyer in connection with a bar admission application or in connection with a disciplinary matter, shall not: (a) knowingly make a false statement of material fact ..." IND. PROF. COND. R. 8.1(a) (2019).

18. Welke, 131 N.E.3d at 163 . Rule 1.1 provides, "[a] lawyer shall provide competent representation to a client. Competent representation requires the legal knowledge, skill, thoroughness and preparation reasonably necessary for the representation." IND. PROF. COND. R. 1.1 (2019).

19. Welke, 131 N.E.3d at 163 . Rule 1.3 provides, "[a] lawyer shall act with reasonable diligence and promptness in representing a client.” IND. PROF. COND. R. 1.3 (2019).

20. Welke, 131 N.E.3d at 163. Rule 1.4(a)(2) provides, "[a] lawyer shall . . (2) reasonably consult with the client about the means by which the client's objectives are to be accomplished". IND. Prof. COND. R. 1.4(a)(2) (2019).

21. Welke, 131 N.E.3d at 163 . Rule 5.3(b) provides, "[w]ith respect to a nonlawyer employed or retained by or associated with a lawyer ... (b) a lawyer having direct supervisory authority over the nonlawyer shall make reasonable efforts to ensure that the person's conduct is compatible with the professional obligations of the lawyer.” IND. PROF. COND. R. 5.3(b) (2019). 
were making a false statement during a disciplinary investigation (rule 8.1(a)), failing to provide competent representation (Rule 1.1), failing to exercise reasonable diligence in a representation (Rule 1.3), failing to consult with the client about the ways the objectives of the representation would be pursued (Rule 1.4(a)(2)), and failing to ensure that Everroad's conduct as a nonlawyer assistant was compatible with the respondent's own professional obligations (Rule 5.3(b)).

The supreme court spent a significant portion of its opinion considering what might be the appropriate sanction to impose for this misconduct. It noted first that this was the respondent's fourth disciplinary action ${ }^{22}$ that painted "the picture of an attorney whose primary motivation appear[ed] to be the collection of legal fees rather than the delivery of valuable services for his clients." ${ }^{23}$ The hearing officer-who took the evidence in the case - described the case as a "bait and switch" representation." 24 The client had been well represented by a public defender, but the respondent and Everroad played on inaccurate stereotypes of public defenders to take advantage of a vulnerable client and his family to "lure[]" the client away at the last minute-for a price. ${ }^{25}$ The Court noted that even a comparable outcome for the client was impossible after the respondent got his fee and neglected the representation. ${ }^{26}$

In the end, switching from the public defender to Respondent earned Client a lighter wallet, comprehensively shoddier legal representation, weakened bargaining power, the inability to meaningfully participate in his own defense, and, ultimately, a high-level conviction and several more years in prison than he otherwise would have received. Whether measured in terms of process or outcome, the prejudice suffered by Client as a result of Respondent's misconduct was severe. ${ }^{27}$

The court noted that the Disciplinary Commission had not asked for disbarment and the hearing officer's recommendation was for a lengthy suspension. Hence, it imposed a three-year suspension. ${ }^{28}$ It is worth noting that any suspension over six months long requires the respondent to go through the reinstatement process. ${ }^{29}$ That process adds months to the time of suspension.

22. Welke, 131 N.E.3d at 164 n.3. See In re Welke, 53 N.E.3d 408 (Ind. 2016) (resulting in a thirty-day suspension for false advertising); In re Welke, 772 N.E.2d 992 (Ind. 2002) (resulting in a thirty-day suspension for unreasonable fees and failing to withdraw from a representation); In re Welke, No. 13S00-9808-DI-460 (resulting in a private administrative admonition).

23. Welke, 131 N.E.3d at 165.

24. Id.

25. $I d$.

26. $I d$.

27. $I d$.

28. Id.

29. IND. ADMIS. DisC. R. $23 \S 3(\mathrm{a})$. Under this process, the lawyer must take and pass the Multistate Professional Responsibility Examination, file a petition for reinstatement, and bears the burden of proving their fitness to return to practice - including a demonstration of remorse. IND. ADMIS. DisC. R. $23 \S 18$. 


\section{IN RE TEMPEL, 130 N.E.3D 94 (IND. 2019)}

This order from the Supreme Court was the result of a settlement reached between the Disciplinary Commission and the respondent lawyer. ${ }^{30}$ Here, the respondent lawyer pleaded guilty in Marion County to two misdemeanor counts of operating a vehicle while intoxicated (OWI). In addition, the respondent had a prior OWI conviction in Boone County. ${ }^{31}$ Because of this, the respondent had an established involvement with the Judges and Lawyers Assistance Program (JLAP) ${ }^{32}$ At the same time, his criminal probation required him to use a SoberLink device. ${ }^{33}$

The supreme court found that the respondent violated Ind. Prof. Cond. R. $8.4(b)^{34}$ of the Rules of Professional Conduct for committing a criminal act that reflects adversely on the respondent's fitness to practice. Thereafter, it suspended the respondent from practice for ninety days - then stayed that suspension subject to the successful completion of one year of probation which included involvement in JLAP. ${ }^{35}$ All of the justices concurred in accepting the proposed resolution except Chief Justice Rush, who would have imposed a period of active suspension from practice and a longer term of probation given the endangerment involved in the Marion County criminal case. ${ }^{36}$

\section{IN RE QUIRK, 128 N.E3D 454 (IND. 2019)}

The supreme court order was the product of a settlement agreement between the Disciplinary Commission and the respondent. ${ }^{37}$ The Commission's disciplinary complaint consisted of five counts of misconduct.

In Count 1, the respondent settled a personal injury lawsuit on behalf of a

30. In re Temple, 130 N.E.3d at 94 (explaining that, under IND. ADMIS. DisC. R. 23 §12.1(b), disciplinary cases are settled using a document entitled, Statement of Circumstances and Conditional Agreement for Discipline. Parties agree to the facts and law to be presented to the Supreme Court, as well as a proposed resolution of the case. The agreement is conditional in that the Supreme Court is free to reject the proposal if they choose.).

31. Id.

32. The Judges and Lawyers Assistance Program is another agency of the Supreme Court. For details, see IND. ADMIS. DISC. R. 31 and the related Program Guidelines that follow.

33. SoberLink is a well-known technology for checking up on those with chemical use problems who are under someone's supervision. For details on how the program works, see BACtrack View, BACTRACK, https://monitoring.bactrack.com [https://perma.cc/WQG5-YKDE] (last visited May 24, 2020).

34. The rule provides, "[i]t is professional misconduct for a lawyer to . . commit a criminal act that reflects adversely on the lawyer's honesty, trustworthiness or fitness as a lawyer in other respects." Note that the rule does not require a criminal conviction but, instead, can punish a proven criminal act.

35. Id. at 95 .

36. Id.

37. In re Quirk, 128 N.E3d 454 (Ind. 2019). 
client identified as "client 1." Expenses with that case were paid by a third party who had a lien on any recovery. The respondent did not pay the lienholder and, when the lienholder wanted paid, the respondent ignored him. Although he denied any knowledge of the lienholder's interest, the respondent knew or should have known of communications from the lienholder's lawyer. ${ }^{38}$

In Count 2 (similar to Count 1), the respondent settled a personal injury lawsuit on behalf of "client 2" and, as with Client 1, he ignored the third-party lienholder and never reimbursed them. ${ }^{39}$

In Count 3, two criminal defendants (Clients " $3 \mathrm{~A}$ " and " $3 \mathrm{~B}$ ") hired the respondent to represent them but the respondent never got a written informed consent to the potential conflict of interest in their representation. ${ }^{40}$ At some point, the respondent withdrew from the representation of Client $3 \mathrm{~A}$ because of a failure to pay his fee, and the client was thereafter represented by a public defender. Later, Client 3A took a handwritten confession to the respondent's office in an attempt to exonerate Client 3B. The respondent had one of his assistants type up the statement despite knowing Client 3A was represented by a public defender. ${ }^{41}$

Two months later, Client $3 \mathrm{~A}$ was arrested on a new charge and wanted the respondent to represent him on both the old and new matters. In an ex parte meeting with the judge, the respondent wanted to know if Client 3A's bond money could be released as his fee. The judge told him to speak to the prosecutor. At a subsequent hearing, the trial court disqualified the respondent from representing either Client $3 \mathrm{~A}$ or $3 \mathrm{~B} .{ }^{42}$

In Count 4 , the respondent began representing Client 4 in a criminal matter arising from the ownership of dogs that were confiscated and retained by the police and the city's animal shelter. During this time, the respondent's law firm represented the City of Muncie as corporation counsel and the respondent's law partner was counsel for the animal shelter. The respondent never obtained written consent from the city or client 4 about an actual or potential conflict of interest in the dual representation. ${ }^{43}$

Client 4 was ultimately convicted of multiple counts of animal cruelty and possession of animals for fighting contests and later sought post-conviction relief

38. Id.

39. Id.

40. Id. Representing codefendants in criminal matters should immediately raise the specter of conflict of interest in a lawyer's mind. A lawyer should think twice, or even thrice, before undertaking such a representation. Extensive disclosure must be made as well as obtaining comprehensive written waivers of any conflict. These are a must before formalizing the attorneyclient relationship. This protects the clients as well as the lawyer. The Indiana Supreme Court has an excellent case on this subject with a detailed analysis by former Justice Theodore Boehm. In Latta $v$. State, the same lawyer represented a husband and wife in a prosecution for murder resulting in a reversal of the wife's conviction. 743 N.E.2d 1121, 1124 (Ind. 2001).

41. Id.

42. Id.

43. Id. at 455 . 
on grounds that included the respondent's conflict of interest. ${ }^{44}$

Procedurally, the respondent did not respond to the Disciplinary Commission's demand for a response to this grievance and a show cause proceeding was begun but later dismissed when the respondent belatedly complied. $^{45}$

In Count 5, the respondent had been convicted of Criminal Recklessness and Operating While Intoxicated in 2012. Both crimes were class "A" misdemeanors. Under Indiana Admission and Discipline Rule 23, Section 11.1, lawyers are required to report convictions of felonies and misdemeanorsto the Disciplinary Commission. The respondent failed to do so and created an additional basis for disciplinary action. ${ }^{46}$

The respondent was found to have violated a series of the Rules of Professional Conduct in connection with his misconduct here: Rule $1.7^{47}$ (the general rule prohibiting the representation of clients with conflicting interests), Rule $1.9^{48}$ (the rule prohibiting representing a client whose interests are adverse

44. Id.

45. Indiana lawyers have a duty to cooperate with a Disciplinary Commission investigation. The Commission, for example, can "demand" a response to a client complaint (like Client 4's matter here). When the lawyer fails to cooperate with the investigation, the Commission begins a proceeding with the Supreme Court where the Court orders the lawyer to show cause why he or she shouldn't be suspended from practice until they comply with the demand. Several times each year, there are lawyers whose failure to cooperate is so protracted that the Supreme Court suspends them indefinitely and requires them to go through the reinstatement process in order to return to practice. See Admis. Disc. R. $23 \S 10.1$.

46. Id.

47. The full text of the rule reads:

(a) Except as provided in paragraph (b), a lawyer shall not represent a client if the representation involves a concurrent conflict of interest. A concurrent conflict of interest exists if:

(1) the representation of one client will be directly adverse to another client; or

(2) there is a significant risk that the representation of one or more clients will be materially limited by the lawyer's responsibilities to another client, a former client or a third person or by a personal interest of the lawyer.

(b) Notwithstanding the existence of a concurrent conflict of interest under paragraph (a), a lawyer may represent a client if:

(1) the lawyer reasonably believes that the lawyer will be able to provide competent and diligent representation to each affected client;

(2) the representation is not prohibited by law;

(3) the representation does not involve the assertion of a claim by one client against another client represented by the lawyer in the same litigation or other proceeding before a tribunal; and

(4) each affected client gives informed consent, confirmed in writing.

48. The full text of the rule reads:

(a) A lawyer who has formerly represented a client in a matter shall not thereafter represent another person in the same or a substantially related matter in which that 
to a former client), Rule $1.10(\mathrm{a})^{49}$ (the conflict of interest rule prohibiting anyone in the firm from undertaking a representation in direct conflict with another client in the law firm).

The parties agreed, and the Supreme Court accepted, a settlement for a suspension from the practice of law for 180 days without automatic reinstatement. The Court also noted that reinstatement is discretionary. ${ }^{50}$

\section{IN RE DENNEY, 131 N.E.3D 182 (IND. 2019)}

The petitioning lawyer, Louis W. Denney, was suspended for three years without automatic reinstatement in 2013 for violations associated with nine counts of misconduct. ${ }^{51}$

After a trial in the reinstatement case, the hearing officer recommended that Denney be reinstated to practice. ${ }^{52}$ The supreme court recited the elements of the rule that Denney was required to prove in order to be successful on

person's interests are materially adverse to the interests of the former client unless the former client gives informed consent, confirmed in writing.

(b) A lawyer shall not knowingly represent a person in the same or a substantially related matter in which a firm with which the lawyer formerly was associated had previously represented a client

(1) whose interests are materially adverse to that person; and

(2) about whom the lawyer had acquired information protected by Rules 1.6 and 1.9(c) that is material to the matter; unless the former client gives informed consent, confirmed in writing.

(c) A lawyer who has formerly represented a client in a matter or whose present or former firm has formerly represented a client in a matter shall not thereafter:

(1) use information relating to the representation to the disadvantage of the former client except as these Rules would permit or require with respect to a client, or when the information has become generally known; or

(2) reveal information relating to the representation except as these Rules would permit or require with respect to a client.

49. The text of the rule reads:

While lawyers are associated in a firm, none of them shall knowingly represent a client when any one of them practicing alone would be prohibited from doing so by Rules 1.7, 1.9 , or 2.2 unless the prohibition is based on a personal interest of the prohibited lawyer and does not present a significant risk of materially limiting the representation of the client by the remaining lawyers in the firm.

50. In re Quirk, 128 N.E3d at 455 . The reinstatement process can be challenging for the suspended lawyer who has the burden of proving fitness before returning to practice. See supra note 29.

51. See In re Denney, 983 N.E.2d 571, 573 (Ind. 2013). The suspension came after a two-day trial and 56 pages of findings of fact from the Hearing Officer. In their order, the Supreme Court highlighted a number of violations and drew out specific facts the Court found noteworthy in making its decision. The order is worth the reader's time to review.

52. In re Denney, 131 N.E.3d at 182. 
reinstatement. ${ }^{53}$ The court then agreed that he should be allowed to practice on the condition that he pays restitution to one of his aggrieved clients. Accordingly, the Court placed Denney on probation for a period of one year. "During this time Petitioner shall make restitution in the amount of $\$ 3,500$ to the client aggrieved in Court 2 of this matter and then shall provide the Commission with a verified accounting and report of same." 54 The noteworthy feature of this case is that the payment of restitution is not a subject which the supreme court often considers. In an older case, ${ }^{55}$ the court held that ordering restitution is not appropriate in disciplinary actions. ${ }^{56}$ The year before Ackerman, the found in In re Case ${ }^{57}$ that the respondent lawyer could not be reinstated to practice until he proved he had made restitution to his victim. ${ }^{58}$ In a dissenting opinion in that case, former Justice Roger O. DeBruler gives thorough treatment to the subject. ${ }^{59}$ Still, it is not unusual for the Court to order restitution where discipline is imposed in the first instance. ${ }^{60}$

\section{IN RE HULTQUIST, 127 N.E.3D 1172 (IND. 2019)}

This is another settled disciplinary action. In large part, this case might be fairly described as an aggravated neglect of a client matter. The respondent was paid \$2,000 to pursue an appeal with the U.S. Department of Health and Human Services ("HHS"). ${ }^{61}$ He missed the deadline, ultimately filed an untimely appeal, and failed to provide proof of service to HHS. ${ }^{62}$

The client tried repeatedly to contact the respondent before hiring another lawyer to do the work. Although successor counsel was able to cure some of the defects, the appeal was ultimately dismissed as untimely. ${ }^{63}$ The respondent admitted that he neglected the matter as charged under Rule 1.3 of the Rules of Professional Conduct ${ }^{64}$ and failed to keep the client reasonably informed about the status of the matter as required by Rule 1.4(a)(3). ${ }^{65}$ For his misconduct, the

53. See id. at 183.

54. Published Order Granting Conditional Reinstatement to the Practice of Law, 2, In the Matter of Louis Denney, Supreme Court Case No. 18S00-1104-DI-193 (Ind. 2019).

55. In re Ackerman, 330 N.E.2d 322 (Ind. 1975).

56. Id.

57. 311 N.E.2d 797 (Ind. 1974).

58. Id. at 799 .

59. Id.

60. See In re Rogers, 109 N.E.3d 960 (Ind. 2018). There are a constellation of issues surrounding this topic that are not addressed here. Is there a claim arising in contract? Is a jury trial available as a remedy? Are defenses of satisfaction and set-off available? Is there a trebling provision for damages? None of these issues are really suitable for complete treatment in this article, but some awareness of the complexity of the problem is appropriate.

61. In re Hultquist, 127 N.E.3d 1172, 1172 (Ind. 2019).

62. Id.

63. Id.

64. Id.; see Ind. Prof. Cond. R. 1.3.

65. Hultquist, 127 N.E.3d at 1173; Ind. Prof. Cond. R. 1.4(a)(3) (“A lawyer shall: . . (3) 
respondent agreed to accept a public reprimand from the Court.

\section{IN RE GRAY, 126 N.E.3D 805 (IND. 2019)}

This is another case resolved through the settlement process. At all times relevant to this disciplinary action, the respondent was a member of the Indiana bar. In Gray, the United States Patent and Trademark Office ("USPTO") filed a disciplinary complaint against the respondent lawyer in 2016. Gray settled that matter by agreeing to a "consensual exclusion from practice before the USPTO without an admission of misconduct." $" 66$

Based on this information, the Disciplinary Commission pursued a state disciplinary action against the respondent. The parties stipulated that Gray was the sole owner and president of his law firm, The Gray Law Group ("TGLG"). ${ }^{67}$ TGLG represented two companies collectively referred to as "USPC." "Pursuant to TGLG's contract with USPC, TGLG would perform relevant art searches on behalf of USPC's inventor clients and, if able, they would draft and file a provisional patent application on behalf of the inventor client." ${ }^{16}$ USPC charged the inventor clients a separate fee for each step. "TGLG did not enter into separate representation agreements with these clients."70 "The inventor clients interacted primarily with USPC . . . and were not told of the limitations on the representation or how fees would be shared between USPC and TGLG." "TGLG did not obtain the inventor client's written informed consent to TGLG's simultaneous representation of, and ongoing business relationship with, USPC." 72 Looking, for a moment, at the substantive issues in the representation, "TGLG [ ] did not discuss with the inventor clients the relative benefits or drawbacks of a provisional patent application in comparison to available alternatives, such as filing a non-provisional application." "I3 "In December 2016, the USPTO filed a disciplinary complaint against the [Gray]" and he agreed to a voluntary exclusion from their bar without an admission of misconduct. ${ }^{74}$

Gray resolved his Indiana disciplinary action by way of settlement-admitting to violations of the following rules: "1.2(a) (failing to consult with a client about the objectives of the representation), ${ }^{.75} 1.2$ (c) (failing

keep the client reasonably informed about the status of the matter").

66. In re Gray, 126 N.E.3d 805, 806 (Ind. 2019).

67. Id.

68. Id.

69. Id.

70. Id.

71. Id.

72. Id. at 805-06.

73. Id. at 806 .

74. Id.

75. IND. PROF. COND. R. 1.2(a). Rule 1.2 governs that distribution of authority between lawyer and client. The full text provides:

(a) Subject to paragraphs (c) and (d), a lawyer shall abide by a client's decisions concerning the objectives of representation and, as required by Rule 1.4, shall 
to obtain a client's informed consent to limit the scope of the representation) ${ }^{76}$ 1.4(a)(1) (failing to promptly inform a client of any decision or circumstance with respect to which the client's informed consent is required); ${ }^{77} 1.4(\mathrm{a})(2)$ (failing to reasonably consult with a client about the means by which the client's objectives are to be accomplished) $)^{78}$; 1.4(b) (failing to explain a matter to the extent reasonable necessary to permit a client to make informed decisions) ${ }^{79} 1.7$ (representing a client when there is a concurrent conflict of interest without obtaining informed, written consent); ${ }^{80} 1.8(\mathrm{f})$ (improperly accepting compensation for representing a client from one other than the client) $;^{81} 5.1$ (failing to make reasonable efforts to ensure that the conduct of another lawyer over whom the lawyer has direct supervisory authority conforms to the Rules of Professional Conduct); ${ }^{82}$ and 5.4(c) (permitting a person who recommends,

consult with the client as to the means by which they are to be pursued. A lawyer may take such action on behalf of the client as is impliedly authorized to carry out the representation. A lawyer shall abide by a client's decision whether to settle a matter. In a criminal case, the lawyer shall abide by the client's decision, after consultation with the lawyer, as to a plea to be entered, whether to waive jury trial and whether the client will testify.

(b) A lawyer's representation of a client, including representation by appointment, does not constitute an endorsement of the client's political, economic, social or moral views or activities.

(c) A lawyer may limit the scope and objectives of the representation if the limitation is reasonable under the circumstances and the client gives informed consent.

(d) A lawyer shall not counsel a client to engage, or assist a client, in conduct that the lawyer knows is criminal or fraudulent, but a lawyer may discuss the legal consequences of any proposed course of conduct with a client and may counsel or assist a client to make a good faith effort to determine the validity, scope, meaning or application of the law.

76. Ind. Prof. COND. R. 1.2(c).

77. InD. PROF. COND. R. 1.4(a)(1). The text of subsection (1) provides: "(a) A lawyer shall: (1) promptly inform the client of any decision or circumstance with respect to which the client's informed consent, as defined in Rule 1.0(e), is required by these Rules."

78. Ind. Prof. Cond. R. 1.4(a)(2).

79. IND. PROF. COND. R. 1.4(b). Rule 1.4(b) provides, "[a] lawyer shall explain a matter to the extent reasonably necessary to permit the client to make informed decisions regarding the representation."

80. Ind. Prof. Cond. R. 1.7; see also In re Quirk, 128 N.E3d 454, 455 (Ind. 2019).

81. IND. PROF. COND. R. 1.8(f) (governing prohibited conflicts of interest) ("A lawyer shall not accept compensation for representing a client from one other than the client unless: (1) the client gives informed consent; (2) there is no interference with the lawyer's independence of professional judgment or with the client-lawyer relationship; and (3) information relating to representation of a client is protected as required by Rule 1.6.").

82. Ind. Prof. Cond. R. 5.1. The full text of rule 5.1 provides:

(a) A partner in a law firm, and a lawyer who individually or together with other lawyers possess comparable managerial authority in a law firm, shall make 
employs, or pays the lawyer to render legal services for another to direct or regulate the lawyer's professional judgment in rendering such legal services). ${ }^{8384}$ Note that these last two rule violations are in Rule 5 of the Rules of Professional Conduct. Whereas a cursory reading of Rule 1 reveals that it deals exclusively

reasonable efforts to ensure that the firm has in effect measures giving reasonable assurance that all lawyers in the firm conform to the Rules of Professional Conduct.

(b) A lawyer having direct supervisory authority over another lawyer shall make reasonable efforts to ensure that the other lawyer conforms to the Rules of Professional Conduct.

(c) A lawyer shall be responsible for another lawyer's violation of the Rules of Professional Conduct if:

(1) the lawyer orders or, with knowledge of the specific conduct, ratifies the conduct involved; or

(2) the lawyer is a partner or has comparable managerial authority in the law firm in which the other lawyer practices, or has direct supervisory authority over the other lawyer, and knows of the conduct at a time when its consequences can be avoided or mitigated but fails to take reasonable remedial action.

83. Ind. PROF. COND. R. 5.4, which provides:

(a) A lawyer or law firm shall not share legal fees with a nonlawyer, except that:

(1) an agreement by a lawyer with the lawyer's firm, partner, or associate may provide for the payment of money, over a reasonable period of time after the lawyer's death, to the lawyer's estate or to one or more specified persons;

(2) a lawyer who purchases the practice of a deceased, disabled, or disappeared lawyer may, pursuant to the provisions of Rule 1.17, pay to the estate or other representative of that lawyer the agreed upon purchase price; and

(3) a lawyer or law firm may include nonlawyer employees in a compensation or retirement plan, even though the plan is based in whole or in part on a profitsharing arrangement.

(b) A lawyer shall not form a partnership with a nonlawyer if any of the activities of the partnership consist of the practice of law.

(c) A lawyer shall not permit a person who recommends, employs, or pays the lawyer to render legal services for another to direct or regulate the lawyer's professional judgment in rendering such legal services.

(d) A lawyer shall not practice with or in the form of a professional corporation or association authorized to practice law for a profit, if:

(1) a nonlawyer owns any interest therein, except that a fiduciary representative of the estate of a lawyer may hold the stock or interest of the lawyer for a reasonable time during administration;

(2) a nonlawyer is a corporate director or officer thereof or occupies the position of similar responsibility in any form of association other than a corporation; or

(3) a nonlawyer has the right to direct or control the professional judgment of a lawyer.

84. In re Gray, 126 N.E.3d 805, 806 (Ind. 2019). 
with the lawyer's duties to clients, Rule 5 governs the lawyer's duties with colleagues, partners, associates, and support staff. Although the rules here are not complex, they define some of the most long-term professional relationships in a lawyer's career.

For the misconduct described above, the parties agreed that Gray should receive a thirty-day suspension from the practice of law as an appropriate resolution to the misconduct. ${ }^{85}$

VII. IN RE ANANIA, 126 N.E.3D 30 (IND. 2019)

This disciplinary case was submitted to the Supreme Court as a settlement proposal. $^{86}$

Here, a client paid the Respondent a $\$ 5,000$ retainer to "pursue a breach of contract case against an HVAC company." ${ }^{\prime 77}$ The lawyer became nonresponsive thereafter and did not file a complaint against the company. ${ }^{88} \mathrm{He}$ did, however, falsely tell the client he had filed the case but avoided the client's requests for a copy of the filed document. ${ }^{89}$ The client was eventually able to confront the lawyer, who admitted his neglect but promised to file the complaint soon. ${ }^{90}$ The client eventually fired the lawyer who only returned a portion of the file and failed to advise the client on any application of the statute of limitations. ${ }^{91}$

The agreed violations included admission to violating Rules: 1.3 (neglect of a client matter) ${ }^{92} 1.4$ (a) (failure to communicate with the client) ${ }^{93} 1.16$ (d) (upon termination of the representation, the lawyer has an obligation to protect the client's interests and return case file materials), ${ }^{94}$ 8.4(c) (engaging in conduct involving dishonesty, fraud, deceit or misrepresentation) ${ }^{95}$ and 8.4(d) (engaging in conduct prejudicial to the administration of justice). ${ }^{96}$

85. Id

86. In re Anania 126 N.E.3d 30 (Ind. 2019).

87. Id.

88. In re Anania, 126 N.E.3d 30 (Ind. 2019).

89. Id.

90. Id.

91. Id.

92. Ind. PRof. Cond. R. 1.3 (2019).

93. Ind. Prof. Cond. R. 1.4(a) (2019).

94. Ind. Prof. Cond. R. 1.16(d) (2019). Rule 1.16(d) provides,

$[\mathrm{u}]$ pon termination of representation, a lawyer shall take steps to the extent reasonably practicable to protect a client's interests, such as giving reasonable notice to the client, allowing time for employment of other counsel, surrendering papers and property to which the client is entitled and refunding any advance payment of fee or expense that has not been earned or incurred. The lawyer may retain papers relating to the client to the extent permitted by other law.

95. Ind. Prof. Cond. R. 8.4(c) (2019). The text of the rule provides, "It is professional misconduct for a lawyer to engage in conduct involving dishonesty, fraud, deceit or misrepresentation."

96. IND. PROF. COND. R. 8.4(d)(2019) ("It is professional misconduct for a lawyer to engage 
This is a serious combination of violations that is reflected in the sanction. The lawyer, the Commission and the Supreme Court agreed that an appropriate sanction would be a six-month suspension from practice. ${ }^{97}$

\section{IN RE GEHEB, 124 N.E.3D 594 (IND. 2019)}

This case was presented to the Court on a Conditional Agreement for Discipline with an agreed sanction of a six months suspension without automatic reinstatement. ${ }^{98}$ This misconduct revolved around the lawyer's handling of funds in his trust account. ${ }^{99}$ The Court described the misconduct as "pervasive" which included a broad spectrum of wrongdoing. ${ }^{100}$ Without laundry-listing all the conduct, the Court recited that he "fail[ed] to maintain adequate records," repeatedly overdrew the account, commingled his own and client funds, "converted client funds for his personal use," and failed to timely and fully cooperate with the Commission's investigation." " ${ }^{01}$ The lawyer also agreed he engaged in conduct "involving dishonesty, fraud, deceit or misrepresentation." 102

The lawyer's violations included violating Rules 1.15(a) (safekeeping client property) ${ }^{103} 1.15$ (c) (depositing personal funds in the trust account): ${ }^{104} 8.1$ (b) (failure to timely respond to the Commission's demands for information); ${ }^{105}$ and 8.4(b) (committing a criminal act (conversion) that reflects adversely on the

in conduct that is prejudicial to the administration of justice.").

97. In re Anania, 126 N.E.3d 30 (Ind. 2019).

98. In re Geheb, 124 N.E.3d 594 (Ind. 2019).

99. Id. at 595 .

100. Id.

101. Id.

102. Id.; Ind. Prof. Cond. R. 8.4(c) (2019).

103. IND. Prof. COND. R. 1.15(a) (2019). The rule provides,

A lawyer shall hold property of clients or third persons that is in a lawyer's possession in connection with a representation separate from the lawyer's own property. Funds shall be kept in a separate account maintained in the state where the lawyer's office is situated, or elsewhere with the consent of the client or third person. Other property shall be identified as such and appropriately safeguarded. Complete records of such account funds and other property shall be kept by the lawyer and shall be preserved for a period of five years after termination of the representation.

104. IND. Prof. Cond. R. 1.15(c) (2019) ("A lawyer shall deposit into a client trust account legal fees and expenses that have been paid in advance, to be withdrawn by the lawyer only as fees are earned or expenses incurred.”). When Rule 1.15 is read in toto, it is clear that funds belonging to the lawyer may only be held under specific conditions - and then not forever.

105. Ind. Prof. Cond. R. 8.1(b) (2019). The rule reads,

An applicant for admission to the bar, or a lawyer in connection with a bar admission application or in connection with a disciplinary matter, shall not . . . knowingly fail to respond to a lawful demand for information from an admissions or disciplinary authority, except that this Rule does not require disclosure of information otherwise protected by Rule 1.6. 
lawyer's honesty, trustworthiness, or fitness as a lawyer). ${ }^{106}$

In addition to the charges within the Rules of Professional Conduct, the Indiana Supreme Court has created rules for the administration of trust accounts in Admission and Discipline Rule 23, section 29. ${ }^{107}$ The bulk of Rule 23 is the

106. IND. Prof. COND. R. 8.4(b) (2019) ("It is professional misconduct for a lawyer to commit a criminal act that reflects adversely on the lawyer's honesty, trustworthiness or fitness as a lawyer in other respects."). Note that the language here only requires that the lawyer commit a criminal act and does not require a conviction of a criminal act.

107. InD. Admis. Disc. R. 23 29(a) (2019). Rule $23 \S 29$ (a) provides,

(a) Required trust account records. An attorney who is licensed in Indiana shall maintain current financial records as provided for in this Rule and required by Rule 1.15 of the Indiana Rules of Professional Conduct. An attorney shall keep records sufficient to determine, at any time, the amount held for each client or other beneficiary in relation to the total amount held in the trust account as a pooled whole. For each trust or other fiduciary account, attorneys shall create and retain the following records for a period of five (5) years after the conclusion of each matter:

(1) Deposit and disbursement journals containing a record of deposits to and withdrawals from each trust account, specifically identifying the date, source of funds, description, amount, and client or beneficiary of each item deposited; the date, payee, purpose, amount, and client or beneficiary of each item disbursed; and a running total of the balance of the trust account as a pooled whole (an example of a deposit and disbursement journal is appended to this Section as Exhibit A);

(2) Ledgers for all trust accounts showing, for each separate trust client or beneficiary, the amount of funds disbursed or deposited, the date of disbursement or deposit, the source of funds deposited, the payee of funds disbursed, and a running total of the amounts held in trust for each separate client or beneficiary (examples of client ledgers are appended to this Section as Exhibit B);

(3) A ledger detailing the nominal amount of attorney funds held in the account, showing the amount of attorney funds disbursed or deposited, the date of their disbursement or deposit, and a running balance of the amount of attorney funds held in the trust account (an example of a ledger of attorney owned funds is appended to this Section as Exhibit C);

(4) Relevant fee agreements;

(5) All checkbook registers, bank statements, records of deposit, and cancelled checks;

(6) Records of all electronic disbursements from trust accounts, including the name of the person authorizing the disbursement, the date of the disbursement, the name of the recipient, the purpose of the disbursement, and the client or beneficiary for whom the disbursement was made; and

(7) All periodic reconciliation reports for each trust account;

See also IND. ADMIS. Disc. Rule $23 \S 29$ (c) (2019). Rule $23 \S 29(\mathrm{c})$ provides additional requirements: 
operating rule for the Disciplinary Commission, but Article V, section 29 of the rule contains administrative requirements of the rule. As in Geheb, many lawyers disciplined for trust account violations violate these requirements. ${ }^{108}$

Also of note was the Court's recitation of the powerful facts in aggravation that added to the sanction. ${ }^{109}$ The lawyer had prior disciplinary action, engaged

(c) Trust account safeguards.

(1) Attorneys shall deposit all funds held in trust in accounts clearly identified as "trust" or "escrow" accounts. Attorneys shall inform the financial institution of the purpose and identity of each trust account. Funds held in trust include funds held in any fiduciary capacity, whether as attorney, trustee, agent, guardian, executor or otherwise. Trust accounts shall be maintained only in financial institutions approved by the Indiana Supreme Court Disciplinary Commission.

(2) Attorneys shall not pay personal or business expenses directly from a trust account; instead, attorneys shall promptly withdraw fully earned fees from the trust account by first disbursing the fully earned fees to the attorney's personal or business account.

(3) Only an attorney admitted to practice law in Indiana or a person under the direct supervision of the attorney shall be an authorized signatory or authorized to disburse funds from a trust account. If an attorney or law firm delegates authority to disburse funds from a trust account to a person not admitted to practice law in Indiana, this delegation shall be accompanied by safeguards, including at minimum:

(i) All bank statements or periodic account activity statements from the financial institution shall be delivered unopened to and reviewed by an attorney having supervisory authority over the non-attorney signatory, or the supervising attorney shall review the bank statements electronically directly from the financial institution; and

(ii) Responsibility for conducting periodic reconciliations between internal trust account records and periodic trust account activity statements from the financial institution shall be vested in a person who has no authority to disburse funds from the trust account.

(4) All receipts shall be deposited into a trust account intact, and records of deposits should be sufficiently detailed to identify each item deposited.

(5) Disbursements from a trust account shall not be made by a check payable to "cash" or to "bearer." Disbursements from a trust account shall not be made by ATM withdrawal or cash withdrawal.

(6) Provided that the attorney complies with Admission and Discipline Rule 23, Sections 29(a) and 29(c)(5), an attorney may make disbursements from a trust account by means of electronic transfer.

(7) Attorneys shall reconcile their internal trust account records, specifically the records required by Admission and Discipline Rule 23, Section 29(a)(1-3) with the periodic bank account statements from the financial institution.

108. ADMIS. Disc. R. 23 § 29(c).

109. In re Geheb, 124 N.E.3d 594 (Ind. 2019). 
in a pattern of misconduct, had a selfish motive in the misconduct, and substantial experience in practicing law. ${ }^{110}$

IX. IN RE RAQUET, 124 N.E. 3D 595 (IND. 2019)

This case was presented to the Court on a Conditional Agreement for Discipline with an agreed sanction of a six-month suspension, all stayed, subject to successful completion of 180 days' probation. ${ }^{111}$ This misconduct revolved around the lawyer's handling of funds in his trust account.

The lawyer had hired a new bookkeeper to replace his wife. The new employee made several deposits into incorrect accounts. ${ }^{112}$ He hired a Certified Public Accountant to audit the accounts and discovered not only the incorrect discrepancies, but theft by the bookkeeper. In January 2018, the bookkeeper was charged with one felony count of theft and another felony count of forgery. ${ }^{113}$ The audit also uncovered that the lawyer had retained earned fees in the trust account in excess of $\$ 5,000$. Coupled with the fact that he had a prior disciplinary action, the sanction could have been much more severe. The Court, however, also considered a number of facts in mitigation that included Respondent's cooperation with the Disciplinary Commission in the investigation, his remorse, his restitution, and his undertaking of remedial measures. ${ }^{114}$

The lawyer agreed that he violated Rules: 1.15(a) (safekeeping the property of others), ${ }^{115}$ Rule 1.15(b) (more than a nominal amount of the lawyer's own money in the trust account), ${ }^{116}$ and Rule 5.3(b) (making reasonable efforts to make sure the lawyer's employee understands the professional obligations of the lawyer). ${ }^{17}$ In addition, the lawyer agreed to violations of the administrative rules found in Admission and Discipline Rule 23, section 29. ${ }^{118}$

\section{IN RE RICKS, 124 N.E.3D 612 (IND. 2019)}

The disciplinary action was charged in four counts wherein the lawyer essentially neglected and failed to communicate with her clients as required by

110. $I d$.

111. In re Racquet, 124 N.E. 3d 595, 596 (Ind. 2019).

112. Id.

113. $I d$.

114. Id. at 595-96. One of the important resources in evaluating the appropriate sanction in lawyer discipline cases is, ANNOTATED STANDARDS FOR IMPOSING LAWYER SANCTIONS (2d ed. 2019). This book is almost 600 pages of guidelines and cases from all across the country revealing the reasoning used by courts in sanctioning lawyers for their misconduct. The sections on aggravation and mitigation are especially helpful.

115. Ind. PROF. COND. R. 1.15(a) (2019).

116. IND. PROF. COND. R. 1.15(b) (2019) (“A lawyer may deposit his or her own funds reasonably sufficient to maintain a nominal balance in a client trust account.").

117. Ind. PROF. Cond. R. 5.3(b) (2019); Racquet, 124 N.E.3d at 596.

118. IND. ADMIS. Disc. R. $23 \S 29$ (c)(1) \& (c)(4) (2019); Racquet, 124 N.E.3d at 596. 
the rules. ${ }^{119}$ There is much surrounding this case, however, that merits more detailed treatment than simply reciting the client-related misconduct.

The lawyer was found to have violated a constellation of rules related to neglect: Rule 1.3 (neglect of entrusted matters), ${ }^{120}$ Rules 1.4(a)(3), (a)(4), and (b) (failing to maintain meaningful communication with clients), ${ }^{121}$ Rule $1.16(\mathrm{~d})$ (protecting a client's interests upon the termination of the representation), ${ }^{122}$ and Rules 8.1(b) and 8.4(d) [conduct involving dishonest and conduct prejudicial to the administration of justice]. ${ }^{123}$

The case was tried before a hearing officer after the Disciplinary Commission filed both a Complaint and an Amended Complaint. ${ }^{124}$ Despite service, she did not appear, respond, or otherwise participate in the proceedings. ${ }^{125}$ The hearing officer adopted the averments in the Amended Complaint as true, and the lawyer did not contest or appeal any of the findings therein. ${ }^{126}$ The Supreme Court then adopted them as true. The Court had much to say about this lawyer's history and the disciplinary process generally:

In recent years, Respondent also has been the subject of five separate show cause proceedings arising from her noncooperation with investigations by the Commission into grievances filed against Respondent. Further, while outside the record of these disciplinary proceedings, we judicially note that Respondent has been found in contempt of this Court for disobedience to our orders demanding the return of appellate records to the Clerk and, as a sanction, she has been barred from withdrawing further records in cases over which this Court has exercised jurisdiction.

The instant case - the third disciplinary prosecution against Respondent for the same type of systemic negligence that has characterized her career - makes clear that her professional shortcomings have not been remedied and in fact are growing worse. Respondent's refusal to appear or participate in these proceedings, while already on disciplinary probation, reinforces this conclusion. The hearing officer succinctly summed up these aggravating factors and others in concluding that "Respondent cannot be safely recommended to the public as a lawyer who they can trust to handle their affairs." (HO's Report at 26).

To protect the public, and in particular the vulnerable clientele within Respondent's niche practice, we conclude that a lengthy period of

119. In re Ricks, 124 N.E.3d 612, 613-15 (Ind. 2019).

120. Ind. Prof. Cond. R. 1.3 (2019).

121. Ind. Prof. Cond. R. 1.4(a)(3-4) \& 1.4(b) (2019).

122. Ind. Prof. Cond. R. 1.16(d).

123. Ind. Prof. Cond. R. 8.1(b) \& 8.4(d) (2019).

124. In re Ricks, 124 N.E.3d at 613.

125. Id.

126. In re Ricks, 124 N.E.3d at 613 . 
suspension without automatic reinstatement is both necessary and appropriate. In order to gain reinstatement following the conclusion of her minimum term of suspension, Respondent will bear a heavy burden of clearly and convincingly establishing her fitness to resume practice. While there exists very little in this record suggesting Respondent will be capable of doing so, we choose not to close that door entirely. ${ }^{127}$

At that point, a majority of the court imposed a two-year suspension from the bar without automatic reinstatement. ${ }^{128}$ The concurring justices believed that the lawyer should have a shot at proving her fitness to practice at some point in the future. ${ }^{129}$ Two Justices, David and Slaughter, did not share that thought and believed the lawyer should be disbarred. ${ }^{130}$ In Indiana, disbarment is a permanent sanction and no reinstatement is possible. ${ }^{131}$

\section{IN RE KENWORTHY, 121 N.E.3D 537 (IND. 2019)}

This is a very brief order consisting only of three full paragraphs, but it has significance for the bar. On March 11, 2019, the Disciplinary Commission filed a document entitled, "Disciplinary Complaint and [] Petition for Disability Suspension" against the lawyer. ${ }^{132}$ The lawyer had been previously suspended on the basis of a disability on more or less an emergent basis on January 11, 2019. ${ }^{133}$ On April 8, the lawyer filed a response and objection to his suspension, but the Supreme Court determined the Commission's petition was well taken. On May 13, the Court ordered the lawyer suspended indefinitely based on his disability. Because of that determination, the Court decided that no further action was needed on the complaint for disciplinary action, and that part of the case was dismissed. ${ }^{134}$

The disability proceeding is fortunately used very rarely. It is a procedure by which an attorney's license can be suspended because the lawyer is not fit to practice. ${ }^{135}$ At the end of the disability, the lawyer must petition for reinstatement

127. Id. at $615-16$.

128. Id. at 616 (under ADMIS. Disc. R. $23 \S 18$, the Respondent can apply for reinstatement).

129. Id.

130. Id.

131. ADMis. DisC. R. 23 § (a).

132. In re Kenworthy, 121 N.E.3d 537, 537 (Ind. 2019).

133. Id.

134. Id.

135. The disability procedure is found in ADMIS. DISC. R. 23, $\S 19$. For purposes of this article, the relevant provisions are:

(a) Report to the Disciplinary Commission. Any person, including a member of the Disciplinary Commission, a member of the Bar of this State, the Executive Director or designee, or any bar association of this State, may submit a report to the Disciplinary Commission suggesting that an attorney be suspended indefinitely from the practice of law due to disability caused by physical or mental infirmity or by the use of intoxicants or drugs; 
under rule 23 , section 18 . The disability procedure, however, does not require an allegation of misconduct but only that the lawyer's fitness to practice is in question.

\section{IN RE GABRIEL, 120 N.E.3D 189 (IND. 2019)}

The Supreme Court disciplined this lawyer for knowingly disobeying court orders and imposed a ninety-day suspension with automatic reinstatement. ${ }^{136}$ This case was tried to a hearing officer based on the following facts: In 2008, the lawyer moved back to Indiana from California, in part to care for her father who was in deteriorating health. Initially, she was her father's attorney-in-fact, but by 2012, her father's condition had deteriorated to the point where she was appointed his guardian. Sometime around 2014, the father (or, more accurately, the guardianship) received about $\$ 40,000$ from the proceeds from the sale of his home. At about the same time, the lawyer made dozens of payments and withdrawals from the guardianship estate to herself without obtaining any judicial approval. She failed to file required accountings or comply with several orders that she do so. In 2016, the court held her in contempt, appointed a successor guardian, and renewed its order that she file an accounting. She was held in contempt again before her father died in $2016 .{ }^{137}$

The lawyer was ultimately found to have violated Rule $3.4(\mathrm{c})^{138}$ for knowingly disobeying the court's orders. The Disciplinary Commission's Complaint charging her with misconduct also charged her with the commission of a criminal act reflecting adversely on her honesty ${ }^{139}$ but the hearing officer (and, ultimately, the Supreme Court) found that the Commission did not prove criminal conversion by clear and convincing evidence. ${ }^{140}$

In concluding that the lawyer should be suspended for ninety days and

(b) Investigation. The Executive Director shall investigate the allegations and shall make a report to the Disciplinary Commission as soon as practicable; and

(c) Hearing and Petition for Disability Suspension. If the Disciplinary Commission determines that there is good reason to believe that the attorney is under a disability that would justify suspension, the Disciplinary Commission shall hold a hearing to determine if the attorney should be suspended indefinitely. To conduct the hearing, the Disciplinary Commission may request the appointment of a hearing officer as provided in Section 18(b)(4). The hearing officer shall submit findings of fact and a recommendation to the Disciplinary Commission. The Disciplinary Commission may then file with the Supreme Court Clerk a Petition for Disability Suspension, which shall include its findings of fact. The Petition may also include a suggestion that the Supreme Court appoint an Attorney Surrogate under Section 27.

136. In re Gabriel, 120 N.E.3d 189 (Ind. 2019).

137. Id.

138. The Rule provides that a lawyer shall not "knowingly disobey an obligation under the rules of a tribunal except for an open refusal based on an assertion that no valid obligation exists."

139. Id. at 190. (See IND. Prof. Cond. R. 8.4(b) (2019)).

140. Id. at 191. 
thereafter be automatically reinstated, the Court also noted that she was suspended for failing to pay her annual fees to the Court. Thus, she could only be reinstated to practice if she was subject to no other suspensions at that time. ${ }^{141}$

XIII. IN RE COOPER, 114 N.E.3D 478 (IND. 2019)

This matter was the product of a settlement between the Commission and the lawyer. ${ }^{142}$ He agreed to a suspension of 180 days — all but sixty days stayed — and two years' probation subject to monitoring by the Judges and Lawyers Assistance Program (JLAP). ${ }^{143}$

The misconduct involved a series of failed representations wherein he took fees for doing work, failed to communicate with his clients and failed to do any substantive work to advance their cases. He did legal work while suspended from the bar and failed to supervise a paralegal to whom he had assigned work on client files. ${ }^{144}$

He agreed to a series of violations that included Rules 1.1 (competence), ${ }^{145}$ Rule 1.3 (diligence, neglect), ${ }^{146}$ Rules 1.4(a)(2), (3), and (4) (lack of communication), ${ }^{147}$ Rule 5.3(b) (failure to supervise nonlawyer staff), ${ }^{148}$ and Rule 5.5(a) (engaging in the authorized practice of law). ${ }^{149}$ This last may seem unusual - especially since the lawyer had actually been admitted in Indiana - but the Supreme Court had ordered his suspension on other grounds and his continuation to practice constituted a violation of the rule. Other remedies include contempt of the Supreme Court; but, in this case, he practiced law in a jurisdiction where he was not legally able to do so.

XIV. IN RE ROGERS, 109 N.E.3D 960 (IND. 2018)

This lawyer had a long and successful career as a criminal defense lawyer but had a troubling and aggravated neglect of a client's case that cost him his license. ${ }^{150}$ The lawyer's client and his family paid him $\$ 8,000$ for his legal fees and to handle an appeal of the client's conviction. ${ }^{151}$

The lawyer did not file a notice of appeal and the deadline passed. In addition, he did not communicate with the client for several months. Eventually, the client fired the lawyer and requested that counsel be appointed to represent

141. Id. at 192.

142. In re Cooper, 114 N.E.3d 478, 479 (Ind. 2019).

143. Id.

144. Id. at 478 .

145. See Ind. Prof. Cond. R. 1.1 (2019).

146. See Ind. Prof. Cond. R. 1.3 (2019).

147. See Ind. Prof. Cond. R. 1.4(a)(2)-(4).

148. See Ind. Prof. Cond. R. 5.3(b).

149. "A lawyer shall not practice law in a jurisdiction in violation of the regulation of the legal profession in that jurisdiction, or assist another in doing so." IND. PROF. COND. R. 5.5(a).

150. In re Rogers, 109 N.E.3d 960, 961 (Ind. 2018).

151. Id. 
him in a belated appeal. He demanded a refund of his fees and the even to the end of the case, the lawyer did not refund the money. The lawyer repeatedly acknowledged that a refund was owed but no money was ever forthcoming. ${ }^{152}$

The hearing officer and the Supreme Court found that the lawyer violated Rules 1.3 (diligence, neglect), ${ }^{153} 1.4$ (failing to communicate), ${ }^{154}$ and $1.16(\mathrm{~d}$ ) (failing to turn over the client's file). ${ }^{155}$ The Supreme Court, recognizing this was an experienced lawyer, added its own thoughts about this misconduct — and a warning to other lawyers in the process:

Respondent has served his community and profession with distinction for over four decades and, until just recently, had an unblemished disciplinary record. We also are mindful of the significant personal hardship Respondent was experiencing around the time of his neglect of Defendant's appeal. That said, we are deeply concerned about Respondent's ongoing and inexplicable failure, now more than three years later, to issue a refund that Respondent consistently has acknowledged is owed and that Respondent has claimed he is "ready, willing and able" to pay. (Citation omitted) We also are concerned about the relative lack of attention devoted by Respondent to this disciplinary proceeding and to a contemporaneous proceeding involving Respondent's noncooperation with another disciplinary investigation, a shortcoming that Respondent's few pleadings appear to attribute to a heavy caseload. We remind Respondent that attorneys have a duty to cooperate with the disciplinary process. We also take this opportunity to remind Respondent (and all attorneys) that although a commitment to helping others is commendable, clients are best served when an attorney has secured his or her own oxygen mask first. ${ }^{156}$

Then, instead of summarily imposing sanction and concluding their analysis, the Court crafted a unique sanction in an attempt to get the lawyer to make the client whole:

For Respondent's professional misconduct, the Court suspends Respondent for 90 days, effective December 14, 2018. Respondent shall not undertake any new legal matters between service of this order and the effective date of the suspension, and Respondent shall fulfill all the duties of a suspended attorney under Admission and Discipline Rule 23(26). If Respondent makes a full refund and files a verified accounting by March 1, 2019, he shall be automatically reinstated to the practice of law at the conclusion of the 90-day period of suspension. If Respondent does not make a full refund and file a verified accounting by March 1, 2019, then his suspension shall be served without automatic

152. $I d$. at 962 .

153. See Ind. Prof. Cond. R. 1.3 (2019).

154. See Ind. Prof. Cond. R. 1.4 (2019).

155. See Ind. Prof. Cond. R. 1.16(d) (2019); In re Rogers, 109 N.E.3d at 962.

156. Id. 
reinstatement, and Respondent may not thereafter resume practice until he has shown a refund has been made and has satisfied the requirements of Admission and Discipline Rule 23(18)(b). ${ }^{157}$

Within a few months of the conclusion of this case, the lawyer passed away. ${ }^{158}$

\section{IN RE BREWER, 110 N.E.3D 1141 (IND. 2018)}

This lawyer had an extensive collection of neglected cases that resulted in the imposition of a three-year suspension by the Supreme Court. ${ }^{159}$ She was charged with more than a dozen counts of misconduct showing a pattern of misbehavior by the lawyer. In counts one through eleven, she had various criminal and family law cases and neglected every one. ${ }^{160}$ She likewise did not keep them informed, did not attend hearings, and failed to return client files after she was terminated. ${ }^{161}$ In Count 12, she failed to appear at a matter and a bench warrant was issued; law enforcement officers found her incoherent, impaired and in possession of cocaine, marijuana, and paraphernalia. ${ }^{162}$ She was subsequently, criminally charged with a felony, and in Count 13, she failed to cooperate with the Commission's demands for information. ${ }^{163}$

The Supreme Court found she violated Rules 1.3 (diligence), ${ }^{164} 1.4$ (failed to communicate with her clients), ${ }^{165} 1.16$ (d) (failed to promptly return client files), ${ }^{166}$ 8.1(b) (failed to respond to the Commission's demands for information), ${ }^{167}$ and 8.4(b) (committed a criminal act reflecting on their fitness). ${ }^{168}$

In ascertaining the appropriate sanction to impose, the Court outlined the considerations it uses in making this analysis:

Our analysis of appropriate discipline entails consideration of the nature of the misconduct, the duties violated by the respondent, any resulting or

157. Id. at 963 .

158. Bob Kasarda, Well-known defense attorney Larry Rogers dies in Florida, NWI.com (Sept. 24, 2019), https://www.nwitimes.com/news/local/crime-and-courts/well-known-defenseattorney-larry-rogers-dies-in-florida/article_93c3c2b7-d52d-5b51-ba8f-b5085a23bcf1.html [https://perma.cc/UG26-6EA5].

159. In re Brewer, 110 N.E.3d 1141, 1144 (Ind. 2018).

160. Id.

161. Id.

162. Id.

163. Id. at 1142-43.

164. See supra note 19.

165. See supra note 20; see also supra note 58.

166. See supra note 94 .

167. That rule provides a lawyer "in connection with a . . . disciplinary matter" shall not: fail to disclose a fact necessary to correct a misapprehension known by the person to have arisen in the matter, or knowingly fail to respond to a lawful demand for information from an admissions or disciplinary authority, except that this Rule does not require disclosure of information otherwise protected by Rule 1.6.

168. See supra note 106. 
potential harm, the respondent's state of mind, our duty to preserve the integrity of the profession, the risk to the public should we allow the respondent to continue in practice, and matters in mitigation and aggravation. See In re Newman, 958 N.E.2d 792, 800 (Ind. 2011). Respondent was previously disciplined by public reprimand for failing to perfect an appeal for a client. See In re Brewer, 907 N.E.2d 965 (Ind. 2009). In 2017, Respondent was the subject of two show cause proceedings. ${ }^{169}$

The Court ended up suspending the lawyer for three years without automatic reinstatement; at the end of that time she could pursue reinstatement if she chooses to. ${ }^{170}$ "One of the functions of the disciplinary process is to protect the public from attorneys who are, for whatever reason, unfit to practice law." In re Wright, 648 N.E.2d 1148, 1150 (Ind. 1995). Misconduct of the magnitude here has resulted in a lengthy suspension or disbarment. See In re White, 81 N.E.3d 211 (Ind. 2017); In re Pierce, 80 N.E.3d 888 (Ind. 2017); In re Engebretsen, 976 N.E.2d 1225 (Ind. 2012); In re Powell, 893 N.E.2d 729 (Ind. 2008). The Commission has not sought disbarment in this case. The hearing officer recommended that Respondent be suspended for three years without automatic reinstatement. We agree with the hearing officer's recommendation. After the suspension period, Respondent may be reinstated only after proving by clear and convincing evidence all of the factors enumerated in Admission and Discipline Rule 23(18)(b), which include genuine remorse for her misconduct, exemplary conduct since the discipline was imposed, and her fitness to practice law. ${ }^{171}$

\section{IN RE LEWIS, 113 N.E.3D 608 (IND. 2018)}

Like many of the disciplinary cases discussed infra, Lewis involves misconduct that is primarily neglectful and non-communicative in relation to client affairs. ${ }^{172}$ Her disciplinary complaint was charged in six counts-four of which involve misconduct in her handling of client matters related to their personal bankruptcies. One additional count involved unusual misconduct wherein she falsified her annual attorney registration in 2017 by claiming she had an IOLTA ${ }^{173}$ account which turned out to be fictitious. She falsely informed the bankruptcy court that she had a client trust account into which she deposited

169. In re Brewer, 110 N.E.3d at 1143.

170. Id. at 1144. See IND. ADMIS. DisC. R. 23, section 18 for more information about the reinstatement process. Note that the petitioning lawyer bears the burden of proof under that rule to prove their fitness to return to the practice of law.

171. 110 N.E.3d at $1143-44$.

172. In re Lewis, 113 N.E.3d 608 (Ind. 2018).

173. Id. at 609. This stands for Interest On Lawyers Trust Account. See generally IND. ADMIS. Disc. R. 23, section 29. 
funds. ${ }^{174}$ The sixth count of misconduct involved her failure to respond to demands for information from the Disciplinary Commission.

In all, Lewis had a series of rule violations that included Rules 1.1 (competence), ${ }^{175} 1.3$ (diligence, neglect), ${ }^{176} 1.4$ (failing to communicate), ${ }^{177} 1.5$ (a) (unreasonable fee), ${ }^{178} 1.16(\mathrm{~d})$ (failing to refund unearned fees), ${ }^{179} 3.3$ (false statement to a tribunal), ${ }^{180} 3.4$ (c) (disobeying a court order), ${ }^{181} 8.4(\mathrm{~b})$ (committing a criminal act), ${ }^{182} 8.4(\mathrm{c})$ (conduct involving dishonesty), ${ }^{183}$ and 8.4(d) (conduct prejudicial to the administration of justice). ${ }^{184}$

One of the themes present in the cases discussed in the article is the common role that the neglect of entrusted matters plays in the disciplinary problems of lawyers who come to the attention of the Disciplinary Commission and the Indiana Supreme Court. Lewis was disbarred. The Supreme Court succinctly discussed the factors that led them to the conclusion that permanent disbarment was the right result for Lewis.

"In exercising our disciplinary authority, we have an obligation to protect the public and the profession from the tactics of unscrupulous lawyers." In re Johnson, 53 N.E.3d 1177, 1180 (Ind. 2016). Respondent stole clients' funds, neglected clients' cases, and disregarded court orders, all serious transgressions. See In re Pierce, 80 N.E.3d 888, 890 (Ind. 2017). Respondent's misconduct also involved pervasive dishonesty toward clients and the bankruptcy court, and Respondent falsified her attorney registration with the Clerk of this Court. Further, Respondent has evaded numerous attempts by clients to contact her, and she has failed to accept service or participate in these disciplinary proceedings. The seriousness and scope of Respondent's misconduct, and her failure to participate in these proceedings, persuade us that Respondent should be disbarred.

174. 113 N.E.3d at 609.

175. See supra note 15.

176. See supra note 16.

177. See supra note 17 ; see also supra note 65.

178. That rule provides in pertinent part, "A lawyer shall not make an agreement for, charge, or collect an unreasonable fee or an unreasonable amount for expenses."

179. See supra note 81.

180. Rule 3.3(a)(1) provides: "A lawyer shall not knowingly...make a false statement of fact or law to a tribunal or fail to correct a false statement of material fact or law previously made to the tribunal by the lawyer[.]"

181. Rule 3.4(c) provides: "A lawyer shall not ... knowingly disobey an obligation under the rules of a tribunal except for an open refusal based on an assertion that no valid obligation exists[.]"

182. See supra note 91.

183. See supra note 82 .

184. See supra note 83. 